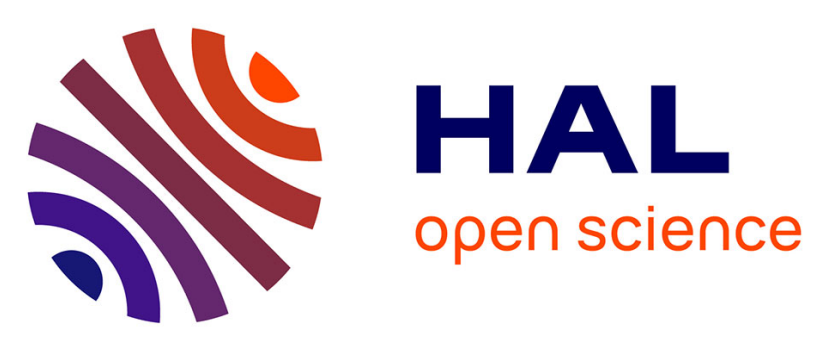

\title{
Microwave dielectric spectroscopy of cell membrane permeabilization with saponin on human B lymphoma cells
}

François Artis, David Dubuc, Jean-Jacques Fournié, Mary Poupot, Katia

Grenier

\section{To cite this version:}

François Artis, David Dubuc, Jean-Jacques Fournié, Mary Poupot, Katia Grenier. Microwave dielectric spectroscopy of cell membrane permeabilization with saponin on human B lymphoma cells. IEEE MTT-S International Microwave Symposium (IMS2014), Jun 2014, Tampa, United States. 4p. hal-01951717

\author{
HAL Id: hal-01951717 \\ https://hal.laas.fr/hal-01951717
}

Submitted on 11 Dec 2018

HAL is a multi-disciplinary open access archive for the deposit and dissemination of scientific research documents, whether they are published or not. The documents may come from teaching and research institutions in France or abroad, or from public or private research centers.
L'archive ouverte pluridisciplinaire HAL, est destinée au dépôt et à la diffusion de documents scientifiques de niveau recherche, publiés ou non, émanant des établissements d'enseignement et de recherche français ou étrangers, des laboratoires publics ou privés. 


\title{
Microwave dielectric spectroscopy of cell membrane permeabilization with saponin on human B lymphoma cells
}

\author{
François Artis $^{1,2}$, David Dubuc ${ }^{1}$, Jean-Jacques Fournié ${ }^{2}$, Mary Poupot ${ }^{2}$, and Katia Grenier ${ }^{1}$ \\ ${ }^{l}$ CNRS, LAAS, Univ. de Toulouse, 7 avenue du colonel Roche, F-31400 Toulouse, France
}

${ }^{2}$ CRCT, Toulouse, France

\begin{abstract}
This paper aims to contribute to the demonstration of the microwave dielectric spectroscopy relevance for biological applications. We demonstrate indeed that microwave dielectric spectroscopy may significantly identify the membrane permeabilization (and its consequence on cells) of cells induced by chemo-treatment. Standard deviations on both real and imaginary parts (resp.) of the permittivity between several experiments are below 0.08 and 0.06 (resp.), whereas the contrasts on these two parameters reach 1.92 and 1.30 (resp.) at $10 \mathrm{GHz}$. The contrasts to the standard deviation ratio are then above 22, which permits to convince the biologists that the technique can significantly and efficiently detect the viability state of a cells population in their traditional culture medium. Moreover, these results permits to predict that such a technique can evaluate the viability of a cells population with few percents of accuracy.
\end{abstract}

Index Terms - Dielectric spectroscopy, biosensor, microwave, microfluidic, biological cells.

\section{INTRODUCTION}

Dielectric spectroscopy techniques are widely recognized for non-destructive material investigations [1]. The technique has also demonstrated its ability for biological analysis especially in the microwave range [2]-[5]. Indeed, at such frequencies, key properties of the electromagnetic waves converge favorably [6]: (1) electromagnetic interaction with aqueous solution is maximized; (2) the waves fully penetrate the biological materials (and living cells especially) and finally (3) the attenuation of microwaves is manageable even in presence of highly ionic solution, as it is the case of traditional culture media. These properties translate into expected microwave readouts, which highly relate the biological parameters of the tissue or cells under investigation.

Microwave dielectric spectroscopy consequently appears to be an attracting alternative to optical, mechanical and lowfrequency electrical approaches for non-invasive biological cell analysis. The technique has therefore to demonstrate its relevance for bio-applications and to convince the biologists of the added value they can expect from such a technique.

This paper aims to contribute to such a demonstration. Miniature microwave dielectric spectroscopy is applied to the probing of permeabilization of cells membrane induced by a chemical treatment. The chosen chemical corresponds to saponin [7], which is traditionally used by biologists to facilitate the penetration of markers in the cells for flow cytometry analysis, without destroying the cells.

Next section presents the developed technique and its integration thanks to micro-technologies. Section 3 details the biological protocol used to permeabilize the cells membrane and to provide counter measurements of cell viability using a strict protocol usually followed by biologists. Fourth section presents the results of microwave spectroscopy of treated and untreated (control) cells and discusses the results regarding the standard deviation featured by the technique.

\section{MICROWAVE DIELECTRIC SPECTROSCOPY APPLIED TO LIVING CELLS: DATA TREATMENT PROTOCOL}

The microwave sensor is constituted of a coplanar waveguide with a microfluidic channel place on top, as shown in Fig. 1. The line is realized with a $0.3 \mu \mathrm{m}$ thick gold layer on a quartz substrate, whereas the fluidic channel is obtained through the photolithography of two SU-8 polymer layers (for walls and lid). The final thermal treatment makes the structure biocompatible.

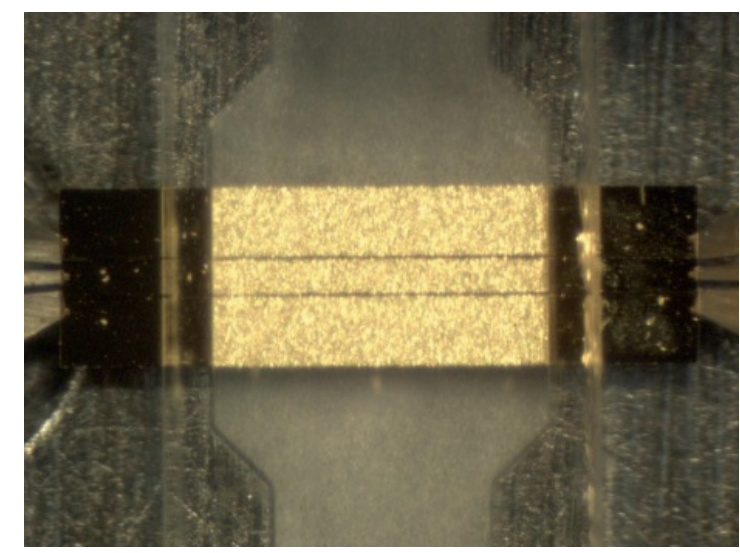

Fig. 1. Photograph of a coplanar line with a SU-8 microfluidic channel on top, which is filled with DOHH-2 cells in suspension at the concentration of 100 millions of cells $/ \mathrm{ml}$.

The measurements are performed on wafer from $40 \mathrm{MHz}$ up to $40 \mathrm{GHz}$. A procedure derived from [8] is applied to extract the real and imaginary parts of the fluid permittivity. Measurements are realized first with pure culture medium and then with cells suspension. We consequently compute the 
contrast between the two complex permittivities, the pure culture medium then states the reference. Section 4 will present the results, as next section details the biological protocol.

\section{BIOLOGICAL PROTOCOL}

DOHH-2 cells, which are commercially available (bought to DSMZ, Braunschweig, Germany), have been used for this study. They correspond to a cultured cells line, employed by biologists for blood cancer investigations. They are cultured at $37^{\circ} \mathrm{C}$ in a humidified incubator with $5 \% \mathrm{CO} 2$ in air, in the RPMI-1640 culture medium supplemented with penicillin, streptomycin (from Cambrex Bio Science, Verviers, Belgium), sodium pyruvate, and $10 \%$ of heat-inactivated FCS (Foetal Calf Serum from Invitrogen Corp., Paisley, UK).

Day of measurements, cells suspension is harvested and centrifuged twice (at $1,200 \mathrm{~g}$ for 5 minutes at room temperature) to refresh the culture medium, which was consumed during cells proliferation. Cells are also set to the right concentration by adjusting the reference medium quantity.

The cell suspension is then splitted into two $1.5 \mathrm{~mL}$ microcentrifuge tubes. One sample is the negative control (untreated cells) and the other tube undergoes the induction of cell death by saponin (treated cells). Actually, saponin (Sigma-Aldrich, St. Louis, MO, USA) can permeabilize cell membranes without destroying them by solubilizing membrane cholesterol and leaving holes in the cell membrane, as indicated in Fig. 2. The nucleus membrane remains intact. Due to the holes in the cytoplasmic membrane, exchange between intracellular and extracellular happens. Therefore, flow cytometry protocols commonly use such a molecule to permeabilize the cell membrane and stain intracellular molecules.

The second microcentrifuge tube is centrifuged and a volume of cell supernatant is replaced by a complete medium mix solution containing saponin at $0.1 \% \mathrm{~m} / \mathrm{v}$ so as the final saponin concentration reaches $0.04 \%$ (mass/volume).

The ADAM-MC (Advanced Detection \& Accurate Measurement ) cell counter (Digital Bio, Seoul, South Korea) is then used to assess viability of both samples.

For each tube, $2 \times 20 \mu \mathrm{L}$ of cell suspension are mixed with $20 \mu \mathrm{L}$ of Digital Bio " $\mathrm{T}$ " solution and $20 \mu \mathrm{L}$ of Digital Bio "N" solution. The first solution contains both lysis buffer and propidium iodide (PI). The lysis buffer leaves holes in both plasmic and nuclear membranes, letting the Propidium Iodide (PI) staining the nuclei (actually the PI is a DNA intercalating agent that becomes fluorescent when bounded to nucleic acids). The second solution only contains PI, which just stains nuclei of apoptotic or necrotic cells, which membranes are not entirely functional. a)

Untreated cell

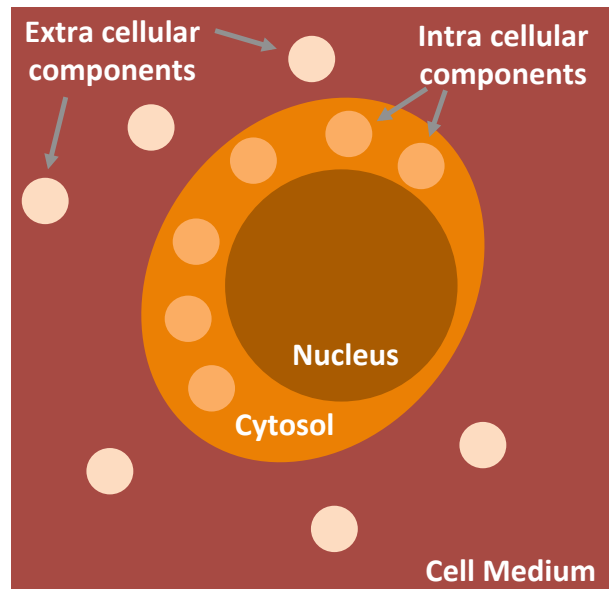

b)

Treated cell

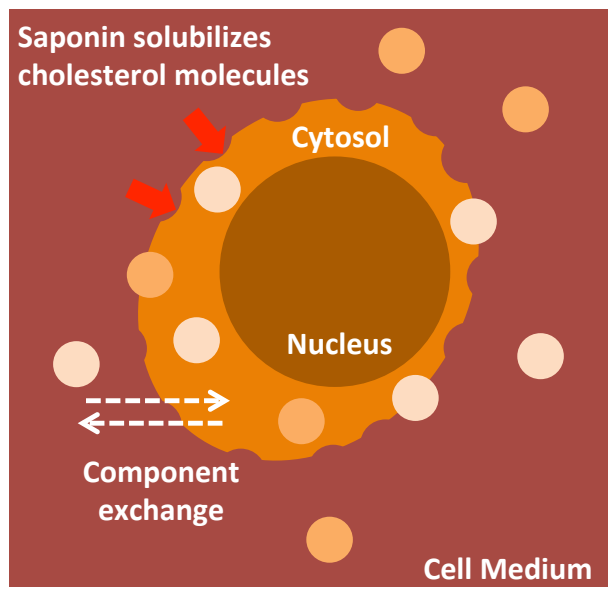

Fig. 2. Schematics of a cell in culture medium, which is a) untreated and b) treated with saponin.

The counting process of large volume of cells using CCD camera detection and automatic image analysis evaluates the number of cells and viability.

\section{RESULTS AND DISCUSSION}

The technique presented in section 2 has been applied to (1) the pure culture medium, which sets the reference, (2) untreated cells suspension, and (3) treated cells suspension with saponin.

Fig. 3 and Fig. 4 present the measured contrasts of the real and imaginary parts of the dielectric permittivity versus frequency for untreated (red curves) and treated (orange curves) cells relative to the pure medium. The measurements have been replicated three times, according to biologists' protocol requirements. 


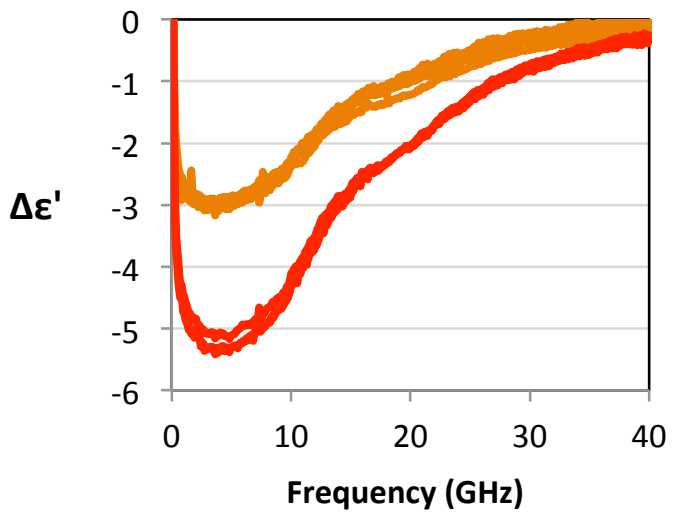

Fig. 3. Dielectric spectra (real part) of treated and untreated DOHH-2 cells.

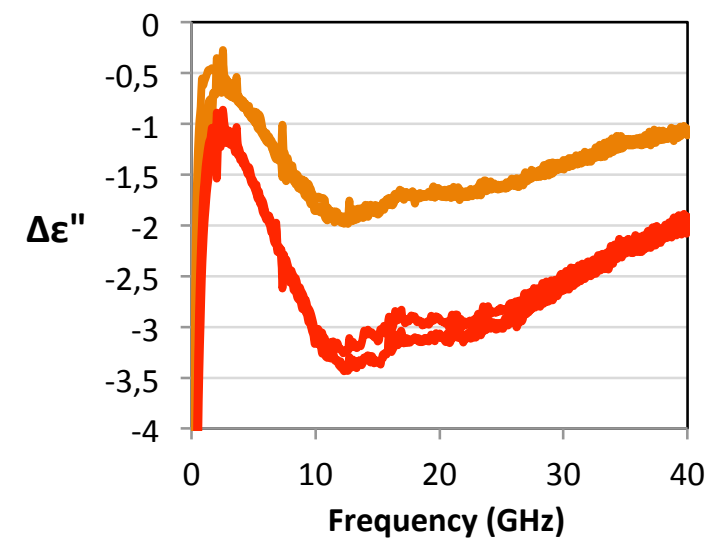

Fig. 4. Dielectric spectra (imaginary part) of treated and untreated DOHH-2 cells.

These figures present high repeatability of measurements as well as clear distinct spectra for treated and untreated cells suspensions. Table I quantifies the dielectric properties of treated and untreated cells suspensions at $10 \mathrm{GHz}$, as well as the standard deviations obtained for both dielectric parameters and finally cells viability obtained with the ADAM-MC cell counter.

Table I. Biological and dielectric properties of treated and untreated cells suspensions at $10 \mathrm{GHz}$

\begin{tabular}{|c|c|c|c|c|c|}
\hline $\begin{array}{c}\text { Properties } \\
\text { at } 10 \mathrm{GHz}\end{array}$ & $\Delta \varepsilon^{\prime}$ & $\operatorname{Std}\left(\Delta \varepsilon^{\prime}\right)$ & $\Delta \varepsilon^{\prime}$ & $\operatorname{Std}\left(\Delta \varepsilon^{\prime}\right)$ & $\begin{array}{c}\text { Cells } \\
\text { Viability }\end{array}$ \\
\hline $\begin{array}{c}\text { Untreated } \\
\text { Cells }\end{array}$ & -4.22 & 0.08 & -3.11 & 0.06 & $90 \%$ \\
\cline { 1 - 2 } \cline { 5 - 6 } $\begin{array}{c}\text { Treated } \\
\text { Cells }\end{array}$ & -2.30 & & -1.81 & & $5 \%$ \\
\hline
\end{tabular}

Standard deviations on both real and imaginary parts (resp.) of the permittivity between several experiments are below 0.08 and 0.06 (resp.). If we normalize these standard deviations with respect to the absolute value of the complex permittivity of the culture medium at $10 \mathrm{GHz}$, the repeatability is as low as $0.2 \%$. This performance points out that microspectroscopy may reveal fine biological information.

Table I, Fig. 3 and Fig. 4 point out that the saponin treatment on cells suspension tends to cancel the dielectric contrast. This reveals that the difference between the dielectric properties of the extracellular and intracellular media is reduced. This result is expected as the saponin treatment induces the membrane permeabilization, which enables leakages of the cytosol in the surrounding culture medium, as already mentioned in Section 3 with the schematics of Fig. 2.

Moreover, the contrasts between treated and untreated cells permittivities reach 1.92 (real part) and 1.30 (imaginary part) at $10 \mathrm{GHz}$. Both values are well above the respective standard deviations, which permit to set that untreated and treated cells suspensions feature significantly different dielectric properties. The contrast to standard deviation ratio is indeed above a value of 22 for a viability variation from 5 to $90 \%$. This result permits to predict that such a technique can evaluate the viability of a cells population with $4 \%$ of accuracy.

\section{CONCLUSIONS}

We demonstrate in this paper that microwave dielectric spectroscopy is a powerful technique for biological investigation as experiments feature repeatability performances as low as $0.2 \%$. To demonstrate such ability, we settle that the technique can significantly identify the membrane permeabilization of cells induced by chemotreatment. Moreover, experimental results permits to convince biologists as the microwave spectroscopy significantly detects the viability of a cells population with an accuracy of $4 \%$.

These performances point out that the microwave dielectric spectroscopy may reveal fine biological information noninvasively.

\section{REFERENCES}

[1] Fredrich Kremer and Andreas Schonhals, "Broadband Dielectric Spectrocopy”, Springer 2003

[2] A. Vander Vorst, A. Rosen and Y. Kotsuka, "RF/ Microwave interaction with biological tissues", IEEE Press, ISBN-10-13, 2006.

[3] C. Gabriel et al., " The dielectric properties of biological tissues: I. Literature survey, » Phys. Med. Bioi, vol. 41, pp. 2231$2249,1996$.

[4] M. A. Stuchly, A. Kraszewski, S. S. Stuchly and A. M. Smith, "Dielectric properties of animal tissues in vivo at radio and microwave frequencies: comparison between species", Phys.Med.Biol, vol. 27, pp. 927-936, 1982.

[5] T. W. Athey, M. A. Stuchly, S. S. Stuchly, "Measurement of radio frequency permittivity of biological tissues with an openended coaxial line : Part I," IEEE Trans. Microwave Theory 
Tech,. vol. 82, pp. 82-86, 1982.

[6] M. Lazebnik, D. Popovic, L. McCartney, C.B. Watkins, M.J. Lindstrom, J. Harter, S. Sewall, T. Ogilvie, A. Magliocco, T.M. Breslin, W. Temple, D. Mew, J.H. Booske, M. Okoniewski, S.C. Hagness, "A large-scale study of the ultrawideband microwave dielectric properties of normal, benign and malignant breast tissues obtained from cancer surgeries," Phys. Med. Biol., vol. 52, pp. 6093-6115, 2007.

[7] M.C. Jacob, M. Favre, and J-C. Bensa, "Membrane Cell Permeabilisation With Saponin and Multiparametric Analysis by Flow Cytometry," Cytometry, Vol. 12, pp. 550-558, 1991.

[8] K. Grenier, D. Dubuc, P-E. Poleni, M. Kumemura, H. Toshiyoshi, T. Fujii, and H. Fujita 'Integrated Broadband Microwave and Microfluidic Sensor dedicated to Bioengineering,' IEEE Trans. on Microwave Theory and Techniques, Vol. 57, n²12, Dec. 2009, pp. 3246-3253. 